\title{
Evolution of the Albanian Constitution
}

\section{Ilda Jeha}

Faculty of Law, University of Tirana

\section{Dr. Ylli Cabiri}

Faculty of Mechanical Engineering, University of Tirana

\section{Doi:10.5901/ajis.2017.v6n1p31}

\begin{abstract}
The history of Albanian Constitutions dates back in April 1914 with the Statute of Albania drafted by a National Committee of that time. The new Albanian Constitution was adopted by the Parliament 18 years ago and confirmed by a Referendum1, becoming the first democratic Constitution following political changes in Albania. After 1991, the stature of Albania changed significantly and the country managed to build new democratic institutions, advanced in establishing a market economy and ensuring human rights, and made important steps towards integration in Euro-Atlantic institutions. In this context, constitutional changes were normal, despite the overall misperception that the Constitution is a document that must not be amended. So, a provisional package of amendments was drafted to avoid obstacles along the way, and a new Constitution was adopted in 1998, later on amended in 2012 and 2016. Analysis of such amendments points out some problems. What should be the procedure for constitutional changes? Parliamentary vote or referendum? In this view, the 2012 constitutional changes - albeit hasty - did not affect the backbone of the document and could be introduced without a referendum, simply with a parliamentary adoption, as was the case. In contrast, the 2016 amendments were adopted unanimously, but they affected the backbone of the Constitution and therefore a referendum should have been called. Should the impact of such amendments be measured? This is another important issue that is not considered actually. But, in our opinion, monitoring any amendments by the Parliament or the President of the Republic is to the benefit of democratic developments and serves any further intentions for constitutional changes. We believe that the Constitution should clearly prescribe the procedure for constitutional changes to save them from becoming a pawn of momentary political interests.
\end{abstract}

\section{The Constitutional Amendments - Theory and Practice}

The debate on the need for frequent amendments to the Constitution remains open in Albania. Should constitutional amendments be made? If yes, through what procedure? When can the referendum be used as a legal instrument? What must be the Parliament's role in these amendments? These are some of the questions raised before lawmakers. Supporters of changes argue that some articles of the constitution reflected Albania's specific situation after the political changes, but now are inadequate to the actual status of the country, particularly in combating widespread corruption in the justice system. This view is strongly supported even by representatives of Albania's ally countries. Opponents of these changes were initially against the idea of constitutional intervention arguing that the Constitution is not a document that can be often and easily modified. This is also the perception of a big number of Albanians who seem to lack proper information about this issue (see Chart 1$)^{2}$.

It is a fact that the Constitution is amended from time to time even in consolidated democracies, in order to match it

\footnotetext{
${ }^{1}$ Referendum for the Constitution held on 22 November 1998.

3 UNDP social-media survey results
} 
to the democratic reality. Hence, the last French Constitution of $1958^{3}$ has been amended 24 times so far "to correct the imperfections or to modify the State's operating rules"4. Changes started since 1960, only two years from its adoption by popular referendum. Even the English Constitution has seen continuous modifications 5 .

Chart 1: Most Albanians perceive Constitution as unchangeable

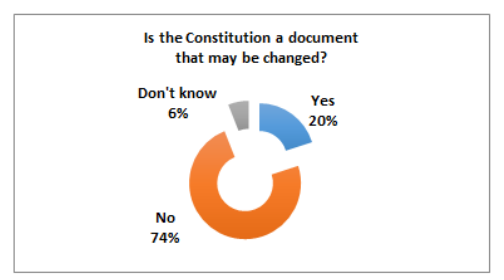

The main problem seems to be not whether the Constitution is to be changed, but the rationale behind changes and their impact. Is the change dictated by momentary narrow-sighted party interests? How necessary is a proposed change? What concrete impact will it generate? How will it fare to the test of time? These and many other questions must be addressed technically and politically, before brining any proposed changes on the table.

On the other hand, the depth of proposed changes is equally important, i.e. these aim at a constitutional overhaul, or just at better adapting the fundamental law to the executive reality? ${ }^{6}$ This is the key argument behind the selection of the adoption procedure for these changes: is the referendum necessary, or changes may simply be adopted in Parliament?

\section{Quick Solution: 1991 Constitutional Package}

Political changes in Albania started with the students protest in December 1990. In June 1991, political forces agreed to establish a joint Government called the Stability Government. The first obstacle to reforms launched by this government was the Constitution; designed for the previous regime, it presented many shortcomings and was not suitable to the market economy model. Here are some of its main shortcomings: (i) From the preface, it referred to the Communist Party and Party of Labour of Albania, State-owned property was considered as the only allowed form of ownership in citizens and villages, and sanctioned the class struggle and the fight against foreign and domestic "enemies"; (ii) it sanctioned the social order, i.e. the dictatorship of proletariat, a one-party system: Party of Labour - the only leading political force of the State and society; and construction of socialism on our own; (iii) it sanctioned the economic order: socialist economy, socialist ownership (State property and cooperative property) over means of production, and personal property: only income from labour and dwelling houses in village 7 ; (iv) it sanctioned that the State leads and develops the whole economic and social life with a unique plan, State monopoly over external trade ${ }^{8}$ and any price; (v) it prohibited the granting of concessions and establishment of joint ventures with foreign companies, as well as foreign loans ${ }^{9}$; (vi) it made the Presidium of the People's Assembly and the People's Assembly the supreme authorities of the State power; and (vii) and sanctioned the defendant's right to defence ${ }^{10}$.

Between the necessity for a new constitution and impossibility to set off and continue the reforms under the democratic system and market economy, the option chosen was a provisional package of constitutional amendments ${ }^{11}$

\footnotetext{
${ }_{4}^{4}$ French Constitution of the Fifth Republic. The first constitution of France was adopted on 3 September 1791.

5 "Peut-on modifier une Costitution?", Paris, 2014.

${ }^{6}$ Nguyen-Duy I., La constitution britanique: continuete etchangement, Paris 2012.

71976 Constitution.

${ }^{8}$ Article 23

${ }^{9}$ Article 27

${ }^{10}$ Article 28

${ }^{11}$ Article 102 - in the sense that the person is not entitled to a lawyer, but may defend themselves.

12 Main constitutional provisions were adopted through Law no 7491, dated 29.4.1991.
} 
that would later be replaced by a new Constitution.

The main constitutions provisions regulated the basic principles of the new democratic State: separation of powers and separation between State and private economy, sanctioned political pluralism, allowed the diversity of property and free initiative, guaranteed the right to establish joint ventures with foreign companies and repatriation of profit. The position of the President of the Republic was introduced by this package. The Stability government was the first having a chance to begin implementation of this document in terms of an unfavorable tradition and not so friendly atmosphere to these changes.

The first attempt to draw up the new Constitution dates back in 1993, but the draft was rejected by popular referendum ${ }^{12}$. Later on, in 1998, another draft was elaborated and adopted by referendum. So, it could be said that democratic Albania had its constitution as of November 1998. Since the adoption of this fundamental document wasn't done any systematic, in-depth analysis by the Parliament, the President of the Republic, political parties or international partners ${ }^{13}$ of how the Constitution meant and represented the rapid development in the country and how it was harmonised with these developments. The occasional changes arguments rely more on political than legal ${ }^{14}$ ones and the political arguments are still dominating. Even those who criticize the changes are mainly based on political arguments and party interests.

But, one of the most serious issues of the actual Constitution is that it fails to guarantee the accountability of the judiciary. While it fully provides for the independence of the judicial system, the Constitution does not guarantee the accountability of this system at the same measure. Judicial power in Albania is a clear example of justice corporatism, where independence (guaranteed by the Constitution) and understood as autonomy, serves as an alibi to avoid accountability and combating corruption.

Independent institutions in Albania are generally established as bi-partisan bodies, reflecting the two-party system installed during the transition period, or, the division into two rival blocks in a perpetual political conflict with one-another. In fact, instead of non-partisan institutions, in Albania we have bi-partisan institutions. In the climate of extreme distrust and polarity, this model does not seem to be functional.

In the bi-partisan model, institutions are built with the principle of sharing the case, or controlling one-another. Experience has shown that - for this model to function - there must be a moderate level of consensus, which is lacking in Albania. Typical examples of these are the continuously contested Central Elections Commission, or the long-blocked Audiovisual Media Authority.

In Albania, political pluralism seems to be perceived as a conflict, rather than as political dialogue; this approach has led to dysfunctional institutions. By paradox, albeit political parties share the same vision and opinion on crucial national development matters, like market economy, EU integration, NATO accession, regional cooperation policies, cooperation with Kosovo - the two main political blocks can hardly reach a compromise or strike a consensus when it comes to actual issues of domestic politics. In Albania, there is a consensus of vision, but not a consensus of action. Compromise is often seen as a sign of weakness, or, otherwise as a right to veto. Meanwhile, political discourse continues to be fierce and quite toxic, and often beyond ethical limits.

These are the reasons why the upcoming constitutional reform must address, first and foremost, issues related to the independence and functioning of the judicial power, including the prosecution office, independent institutions and the constitutional position of the president of the Republic.

\section{The Subsequent Amendments}

The amendments of 2008, partially dealt with these major adjustments. They sanctioned the election of the President of the Republic by 71 votes to avoid political deadlocks, the 5 -year mandate of the Prosecutor General and the regional proportional system for elections, in order to avoid another 'Dushku phenomenon'.

So, it is the general perception that the amendments touched the core of the problem, but had a negative effect on checks and balances, because the Constitution failed to entirely ensure real and effective parliamentary oversight on the

\footnotetext{
${ }^{13}$ Referendum conducted in November 1999, with $84.3 \%$ turnover and $53 \%$ of them against the draft.

${ }^{14}$ Referring mostly to the Venice Commission or the EU-financed EURALIUS programme.

15 Krasniqi A., "Kurthet e reformës kushtetuese", Tirana, 1 May 2008.
} 
government, or as critics randomly say, the parliament resembled more to the notary of the government. The 1998 Constitution is also considered to have failed in ensuring the appropriate protection to independent institutions from the influence of the parliamentary political majority.

In this way, the justice system continued to stay on unstable ground and there was a wrong expectation that the system would be reformed from within, or by the corrupt-perceived judges. Meanwhile, the judges continued to make praise to the system in their analysis, pointing out just any final shortcoming such as the judges' professional deficiencies, inadequate integrity, ineffective constitutional model for the appointment of judges to the High Court or the HCJ Chair position held by the a politically active President of the Republic that creates the premises for political pressure over the judiciary. According to them, the judiciary model is advanced and appropriate and therefore must not be touched, but rather the organic laws deriving from the Constitution and the Codes of Procedures prior to entry into force needed more adjustments to bring them in line with the constitutional norms and principles and European standards ${ }^{15}$. There is a clear intention to maintain the status quo, reflected in the judges' stance towards a justice comprehensive reform.

Surprisingly, these changes were supported by the international partners, seemingly more inclined on the political stability, rather than the stability and democracy in Albania. There is no other explanation to the fact that the justice reform was not considered indispensable by them, and the lack of any serious strategic document assisted by them under this reform, at a time where public Albanian institutions - assisted by international partners - developed over 25 strategic documents, one for virtually each sector or subsector and their Action Plans.

\section{Latest Changes in 2016: Justice Reform}

These changes were initiated by Albanian political parties with the strong support of the international partners who used the EU integration process as an instrument to push for them. This was the reason why the constitutional changes were adopted unanimously by all of the $140 \mathrm{MPs}$.

These amendments had the following main characteristics (i) cosmetic changes that clarified various issues handled "hastily" in the existing Constitution; (ii) fundamental changes to the justice system; and (iii) necessary changes stemming from the fundamental changes.

In all these changes, it is clear that the justice reform is included in the second set of changes. This group argues that the existing institutions of the justice system are inefficient because the existing Constitution cannot ensure their smooth functioning. The same group intervenes in the Constitutional Court ${ }^{16}$ and touches aspects of its organisation and functioning. In fact, the essence of this reform has three benchmarks: (i) self-governance of the justice system; (ii) composition of the justice system; and (ii) architecture of the justice system.

In this view, the amendments of the first and third group could have been adopted in Parliament, as the case was, without the need for popular vote through a constitutional referendum. But, the amendments of the second group affect the existing Constitution deeply, i.e. its chapter about justice, and should have been based on a popular referendum. People's say in such a referendum would have had at least two advantages: (i) it creates a solid tradition that Constitutional changes may be introduced only through popular referendum; and (ii) a massive in favour vote in the referendum is a serious discouragement to anyone who seeks to slow down this vital reform for Albania. Obviously, politicians thought that parliamentary adoption of the constitutional changes was the best option to gain time, because the justice reform had to be accelerated, being a condition for the opening of accession talks for Albania's adherence to the EU. So, contrary to the popular wise saying that the shortest way is the longest way, the politicians fell in the trap of time. So big are the objections that it is not clear yet when implementation of the justice reform is going to kick off.

The main reason behind the objections seems to be related to the legal framework stemming from the constitutional amendments adopted unanimously, particularly to the Vetting Law that regulates the audit of wealth of judges at any level. Besides, once these amendments were adopted in the Parliament, justice experts clearly stated that representatives of the political sphere or stakeholders would resist to the implementation of this reform, despite the adoption of these constitutional amendments ${ }^{17}$.

${ }^{15}$ Avdiu F.- former Chair of High Court, Judicial Power in the Republic of Albania -achievements and challenges in the reform process, Telegraf newspaper, 30 July 2012

16 Law no. 99/2016, "On some addenda and amendments to Law no. 8577, dated 10.2.2000 'On the organisational and functioning of the Constitutional Court", September 2016.

17 Hazizaj S., "Justice reform and post-reform challenges", Interview for Radio Deutsche Welle, 29 July 2016. 
And quite promptly, the political opposition sent the Vetting Law to the Constitutional Court for consideration and was not confirmed by the President of the Republic. This Court sent it for competence to the Venice Commission. It was the Commission which proposed the law in the first place; therefore it is providing an opinion in favour of it. Then, another claim was raised: the document sent to Venice had translation mistakes. Immediately, an association of judges re-sent the law for consideration to the Constitutional Court.

The reasons of such resistance are not very clear, probably influenced by several political reasons, given the upcoming elections next year.

Evidently, most publications by justice experts notice their sometimes silent and "professional" resistance to indepth reformation. The proposed system is labelled "experimental", unknown to any democratic country, and the reform presents challenges that need to be tackled; what compromised the actual system is the poor enforcement of the laws which are recognised as embedding the best international standards; some changes could be made in courts and prosecution offices to prevent overlapping actions. The main argument is that the system is experimental and, as in any experiment, you might succeed or you might fail. Then, there comes a clear warning: the reform is becoming like a fragile creation, things are attempting to be done without much maturity by passing consultation with representatives of courts and prosecution offices ${ }^{18}$.

From all these "arguments", it is obvious that the judges tend to maintain the status quo of the existing system, implying that allegations about their conflict of interest probably have some grounds, after all.

The justice reform is wrongly perceived as a 'one-stop-shop' reform. In fact, it is a deep and continuous reform that must not be limited to the Vetting Law. It only starts off with this law. Therefore, it is very important that anyone has a thorough understanding of the reform, the expectations from it would be more realistic.

However, this reform seems to be indispensable and is expected impatiently by all, including international partners ${ }^{19}$. But, nobody has been able to provide a clear answer to questions like when will the reform start from, or when will the public feel the effects of justice reform ${ }^{20}$.

\section{Conclusions and Recommendations}

Constitutional amendments must be technically reasoned and should not be made based only on political arguments and for narrow-sighted political interest. Because, the Constitution must not be considered as the fundamental document for parties, but for the State and citizens.

Selected procedure governing the amendments should be clear, transparent to all and binding. Crucial constitutional amendments must be adopted in Parliament and be confirmed by a popular referendum.

Other amendments could be adopted simply by the Parliament. But the Constitution must clearly provide for each processes; at least, by stipulating some selection criteria in order to avoid interpretations driven by political interests.

The impact of any constitutional amendments must be measured periodically. For this, a monitoring unit at the President's Office ought to be established to report to the Parliament each year about the impact of such changes. Such a report would also prevent any a priori assessments made by political parties of constitutional changes made.

All must adhere to the justice reform, most of all politicians and judges. They must know the reform in detail. An Action Plan outligning the steps for the implementation of the reform would be useful to both politicians and the public at large.

\section{References}

UNDP Tirana, The Human Development Report - Albania 2016, Tirana June 2016.

Ligj Nr. 5506, datë 28.12.1976: Kushtetuta e Republikës Popullore Socialiste të Shqipërisë.

Nguyen-Duy I., La constitution britanique: continuete et changement, Paris 2012

Krasniqi A., Kurthet e reformës kushtetuese, Tiranë, 1 maj 2008

Meta l., Rama të mos gabojë si në 2008-tën, GazetaShqip, 4 nëntor 2015.

Avdiu F.-ish kryetar i Gjykatës së Lartë, Pushteti gjyqësor në Republikën e Shqipërisë - arritje dhe sfida në procesin e reformimit,

${ }^{19}$ Muci Sh., former Minister of Justice, Interview on Radio Deutsche Welle, 29.7.2016.

20 Zaganjori Xh., Anastasi A., Cani E., "Shteti i së drejtës në Kushtetutën e Shqipërisë", publication by Conrad Adenauers - Stiftung Albania, 2016.

${ }^{21}$ Gegvataj A., Miratimi i ndryshimeve kushtetuese për reformën në drejtësi, ATSH, 28 korrik 2016. 
Gazeta Telegraf, 30 korrik 2012

Hazizaj S., Reforma në drejtësi dhe sfida e post-reformës, Intervistë për radion Deutsche Welle, 29 korrik 2016.

Muci Sh., ish Ministër i Drejtësisë, Reforma në drejtësi dhe sfida e post-reformës, intervistë në radion Deutsche Welle, 29.7.2016;

Zaganjori Xh., Anastasi A., Cani E., Shteti i së drejtës në Kushtetutën e Shqipërisë, publikim i Conrad Adenauers - Stiftung, Shqipëri, 2016.

Gegvataj A., Miratimi i ndryshimeve kushtetuese për reformën në drejtësi, ATSH, 28 korrik 2016;

Ligj Nr. 99/2016, Per dissa shtesa e ndryshime në ligjin Nr. 8577 datë 10.2.2000, për organizimin dhe funksionimin e Gjykatës Kushtetuese, Tiranë 2016. 